\title{
An Improved Grunwald-Letnikov Fractional Differential Mask for Image Texture Enhancement
}

\author{
Vishwadeep Garg \\ Research Scholar, Electronics and Communication \\ Engineering Department \\ Thapar University \\ Patiala, India
}

\begin{abstract}
Texture plays an important role in identification of objects or regions of interest in an image. In order to enhance this textural information and overcome the limitations of the classical derivative operators a two-dimensional fractional differential operator is discussed, which is an improved version of the Grunwald-Letnikov (G-L) based fractional differential operator. A two dimensional-isotropic gradient operator mask based on G$\mathrm{L}$ fractional differential is constructed. This nonlinear filter mask is implemented on various texture enriched digital images and enhancement of features of image is controlled by varying the intensity factor. In order to analyze the enhancement quantitatively, information entropy and average gradient are the parameters used. The results show that with improved version of Grunwald-Letnikov, fractional differential operator information entropy of image is improved by 0.5 .
\end{abstract}

Keywords-texture enhancement; fractional differential; information entropy; average gradient.

\section{INTRODUCTION}

Texture is an innate property of virtually all surfaces which contain important information about structural arrangement of surfaces and their relation to surrounding environment [1]. Since, the textural properties of image carry useful information for discrimination purpose hence enhancement of these textural features is an important concern. Contrast enhancement and image sharpening are known general techniques that can enhance subtle texture of an image. The contrast enhancement techniques are discussed in [2]. The classical image sharpening techniques are based on integral derivative operators like Sobel, Prewitts and Laplacian. Recently, many methods like Laplacian Pyramid, Curvelet Transform and Wavelets are introduced in [3]-[6] in order to enhance the texture information. In recent years with phenomenal research in the field of fractional calculus, it finds an important place in the field of signal processing and digital image processing. The concept of fractional calculus came into existence in 1695 with discussion between Leibniz and L'Hospital. In relation to fractional calculus, three popular definitions are known till date which is Grunwald-Letnikov (G-L), Riemann-Liouville (R-L) and Caputo [7]-[9]. Of these G-L and R-L are the popular definitions used in digital image processing. G-L based differential operator is adopted by many researchers and scholars in [10]-[12]. Recent research has been made to construct R-L based fractional differential operator presented in [13]-[14]. Although both G-L and R-L based differential

\author{
Kulbir Singh \\ Associate Professor, Electronics and Communication \\ Engineering Department \\ Thapar University \\ Patiala, India
}

operator overcomes the deficiencies of the classical gradient operators yet they suffer from some distortion. In this paper, an improved G-L fractional differential operator is presented to process digital image.

\section{FRACTIONAL DIFFERENTIATION}

In this section, theoretical background of GrunwaldLetnikov (G-L) based fractional differential is considered. G-L definition of fractional calculus arises from classical definition of integral differentiation by generalizing differential order from integer to fraction. Assuming $\forall \mathrm{v} \in \mathrm{R}$ ( $\mathrm{R}$ represents real set and, [v] is its integral part) and signal $s(t) \in[a, t], a<t$, $\mathrm{a} \in \mathrm{R}, \mathrm{t} \in \mathrm{R}$ has $\mathrm{m}(\mathrm{m} \in \mathrm{Z}, \mathrm{Z}$ represents integer set) order continuous differentiation. When $\mathrm{v}>0$, so v-order fractional

$$
D_{t}^{v} s(t)=\lim _{h \rightarrow 0} s_{h}^{v}(t)=\lim _{h \rightarrow 0} h^{-v} \sum_{m=0}^{n-1}\left(\begin{array}{l}
-v \\
m
\end{array}\right) s(t-m h)
$$

where

$$
\left(\begin{array}{l}
-\mathrm{v} \\
\mathrm{m}
\end{array}\right)=\frac{(-\mathrm{v})(-\mathrm{v}+1) \cdots(-\mathrm{v}+\mathrm{m}-1)}{\mathrm{m} !}
$$

Thus,

$$
\mathrm{D}_{\mathrm{t}}^{\mathrm{v}}=\frac{\mathrm{h}^{-\mathrm{v}}}{\Gamma(-\mathrm{v})} \sum_{\mathrm{m}=0}^{\mathrm{n}-1} \frac{\Gamma(\mathrm{m}-\mathrm{v})}{\Gamma(\mathrm{m}+1)} \mathrm{s}(\mathrm{t}-\mathrm{mh})
$$

Taking the duration of signal $\mathrm{h}=1$, the dispersion expression of one-dimensional signals fractional differential is expressed as

$$
\begin{aligned}
& \frac{\mathrm{d}^{\mathrm{v}} \mathrm{s}(\mathrm{t})}{\mathrm{dt}^{\mathrm{v}}} \approx \mathrm{s}(\mathrm{t})+(-\mathrm{v}) \mathrm{s}(\mathrm{t}-1)+\frac{(-\mathrm{v})(-\mathrm{v}+1)}{2} \mathrm{~s}(\mathrm{t}-2) \\
& +\frac{(-v)(-v+1)(-v+2)}{6} s(t-3) \cdots \\
& +\frac{\Gamma(\mathrm{n}-\mathrm{v})}{\Gamma(-\mathrm{v}) \Gamma(\mathrm{n}+1)} \mathrm{s}(\mathrm{t}-\mathrm{n})
\end{aligned}
$$

From except the first term the other $\mathrm{n}-1$ nonzero coefficients are functions with respect to fractional order $\mathrm{v}$. It can be observed that sum of $n$ nonzero coefficient is nonzero, which is the significant difference between integral and fractional differential. 


\section{AN IMPROVED G-L FRACTIONAL DifFERENTIAL}

In order to make fractional differential operator more precise (3) can be rewritten as [15]

$$
\mathrm{D}_{\mathrm{t}}^{\mathrm{v}}=\frac{\mathrm{h}^{-\mathrm{v}}}{\Gamma(-\mathrm{v})} \sum_{\mathrm{m}=0}^{\mathrm{n}-1} \frac{\Gamma(\mathrm{m}-\mathrm{v})}{\Gamma(\mathrm{m}+1)} \mathrm{s}\left(\mathrm{t}+\frac{\mathrm{vh}}{2}-\mathrm{mh}\right)
$$

Comparing (4) and (5), (5) have introduced the signal values of $\mathrm{s}(\mathrm{t})$ on nonnodes besides supposing $\mathrm{v}=0, \pm 2, \pm 4, \ldots \ldots$, thus considering the three nodes $\mathrm{s}(\mathrm{t}+\mathrm{h}-\mathrm{mh}), \mathrm{s}(\mathrm{t}-\mathrm{mh})$ and $\mathrm{s}(\mathrm{t}-\mathrm{h}-\mathrm{mh})$ and with 3-point Lagrange interpolation expression it implies

$$
\begin{gathered}
\mathrm{s}(\xi) \approx \frac{(\xi-\mathrm{t}+\mathrm{mh})(\xi-\mathrm{t}-\mathrm{h}+\mathrm{mh})}{2 \mathrm{~h}^{2}} \mathrm{~s}(\mathrm{t}+\mathrm{h}-\mathrm{mh}) \\
-\frac{(\xi-\mathrm{t}-\mathrm{h}+\mathrm{mh})(\xi-\mathrm{t}+\mathrm{h}+\mathrm{mh})}{\mathrm{h}^{2}} \mathrm{~s}(\mathrm{t}-\mathrm{mh}) \\
+\frac{(\xi-\mathrm{t}-\mathrm{h}+\mathrm{mh})(\xi-\mathrm{t}+\mathrm{mh})}{2 \mathrm{~h}^{2}} \mathrm{~s}(\mathrm{t}-\mathrm{h}-\mathrm{mh})
\end{gathered}
$$

Assuming $\xi=\mathrm{t}+(\mathrm{vh} / 2)-\mathrm{mh}$ and doing fractional interpolation (6) can be written as

$$
\begin{aligned}
\mathrm{s}\left(\mathrm{t}+\frac{\mathrm{vh}}{2}-\mathrm{mh}\right) \cong & \left(\frac{\mathrm{v}}{4}+\frac{\mathrm{v}^{2}}{8}\right) \mathrm{s}(\mathrm{t}+\mathrm{h}-\mathrm{mh}) \\
& +\left(1-\frac{\mathrm{v}^{2}}{4}\right) \mathrm{s}(\mathrm{t}-\mathrm{mh}) \\
& +\left(\frac{\mathrm{v}^{2}}{8}-\frac{\mathrm{v}}{4}\right) \mathrm{s}(\mathrm{t}-\mathrm{h}-\mathrm{mh})
\end{aligned}
$$

From (5) and (7)

$$
\begin{aligned}
& \frac{\partial^{\mathrm{v}}}{\partial \mathrm{t}} \mathrm{s}(\mathrm{t})=\frac{\mathrm{h}^{-\mathrm{v}}}{\Gamma(-\mathrm{v})} \sum_{\mathrm{m}=0}^{\mathrm{n}-1} \frac{\Gamma(\mathrm{m}-\mathrm{v})}{\Gamma(\mathrm{m}+1)} \\
& \times\left[\mathrm{s}_{\mathrm{m}}+\frac{\mathrm{v}}{4}\left(\mathrm{~s}_{\mathrm{m}-1}-\mathrm{s}_{\mathrm{m}+1}\right)+\frac{\mathrm{v}^{2}}{8}\left(\mathrm{~s}_{\mathrm{m}-1}-2 \mathrm{~s}_{\mathrm{m}}+\mathrm{s}_{\mathrm{m}+1}\right)\right]
\end{aligned}
$$

where $\quad \mathrm{s}_{\mathrm{m}}=\mathrm{s}(\mathrm{t}-\mathrm{mh}), \quad \mathrm{s}_{\mathrm{m}-1}=\mathrm{s}(\mathrm{t}+\mathrm{h}-\mathrm{mh}) \quad$ and $\mathrm{s}_{\mathrm{m}+1}=\mathrm{s}(\mathrm{t}-\mathrm{h}-\mathrm{mh})$

This is an expression of an improved G-L Fractional Differential [15]

\section{DESIGN Of AN IMPROVED G-L FraCtionaL DIFFERENTIAL}

Image processing with a nonlinear filter consists of moving the filter mask from point to point in an image. This linear filtering operation is given by expression [14]

$$
g(x, y)=\sum_{s=-a}^{a} \sum_{t=-b}^{b} w(s, t) f(x+s, y+t)
$$

where $f(x, y)$ is a value of pixel and $w(s, t)$ is a value of mask. Considering the gradient direction, the mask is designed into an $\mathrm{m} \times \mathrm{m}$-size matrix $\mathrm{T}$ which has $\mathrm{m}$ layers ( $\mathrm{m}$ is odd natural number).

There are 8 directions of $\mathrm{T}$, which are $0, \pi / 8, \pi / 4,3 \pi / 8, \pi / 2$, $5 \pi / 8,3 \pi / 4$ and $7 \pi / 8$, respectively. From (8) it is concluded that

$$
\mathrm{T}_{\mathrm{i}}=\frac{1}{\Gamma(-\mathrm{v})}\left[\begin{array}{r}
\frac{\Gamma(\mathrm{i}-\mathrm{v}+1)}{(\mathrm{i}+1) !}+\frac{\Gamma(\mathrm{i}-\mathrm{v})}{\mathrm{i} !}\left(1-\frac{\mathrm{v}^{2}}{4}\right) \\
+\frac{\Gamma(\mathrm{i}-\mathrm{v}-1)}{(\mathrm{i}-1) !}\left(-\frac{\mathrm{v}}{4}+\frac{\mathrm{v}^{2}}{8}\right)
\end{array}\right]
$$

where $T_{i}$ is the value of $i^{\text {th }}$ layer of mask, $v \in R^{+}$ [14]

Especially, in order to make the sum of $\mathrm{T}$ equal to 0 , it has

$$
\mathrm{T}_{0}=-1 * \sum_{\mathrm{i}=1}^{\mathrm{n}} 8 * \mathrm{i} * \mathrm{~T}_{\mathrm{i}}
$$

Clearly, the result of convoluting with $\mathrm{T}$ is the sharpening edges of the image.

For the purpose of texture enhancement, the sharpening edges must add to the value of original pixel

So $T$ must change into $R$

$$
\begin{cases}\mathrm{R}_{\mathrm{i}}=\gamma \mathrm{T}_{\mathrm{i}} & ;(\mathrm{i}>0) \\ \mathrm{R}_{0}=(1+\gamma) \mathrm{T}_{0} & ;(\mathrm{i}=0)\end{cases}
$$

where $\gamma$ is the intensity factor.

When $v \in(0,1)$ from (11) and (12)

$$
\begin{cases}\mathrm{R}_{\mathrm{i}}=\gamma \mathrm{T}_{\mathrm{i}} & ;(\mathrm{i}>0) \\ \mathrm{R}_{0}=1-\sum_{\mathrm{i}=1}^{\mathrm{n}} 8 * \mathrm{i}^{*} \mathrm{R}_{\mathrm{i}} & ;(\mathrm{i}=0)\end{cases}
$$

The mask of an improved G-L fractional differential is shown in Fig. 1(a)

\begin{tabular}{|l|l|l|}
\hline R1 & R1 & R1 \\
\hline R1 & R0 & R1 \\
\hline R1 & R1 & R1 \\
\hline
\end{tabular}

\begin{tabular}{|l|l|l|}
\hline-0.2474 & -0.2474 & -0.2474 \\
\hline-0.2474 & 2.9792 & -0.2474 \\
\hline-0.2474 & -0.2474 & -0.2474 \\
\hline
\end{tabular}

(a)

(b)

Figure 1. (a) A 3 X 3 size mask of an improved G-L Fractional Differential. (b) A $3 \times 3$ size filter mask at $\mathrm{v}=0.5$ and intensity factor $\gamma=1$

It is seen from Fig. 1(b) that sum of coefficients of mask is not equal to zero which is a prominent difference between fractional and integral differential. 


\section{Simulated Results And AnAlysis}

The Fractional Differential mask discussed above is implemented on images, and image texture enhancement is analyzed by varying mask parameters.

\section{A. Comparative Analysis with Other Fractional Differential Masks}

The intensity factor of an image is kept constant at $\gamma=1$ and the fractional differential order $(\mathrm{v})$ is varied for $0<\mathrm{v}<1$. The simulated results through Grunwald-Letnikov (G-L), Riemann-Liouville (R-L) and Improved G-L Fractional Differential (FD) Masks are presented in Fig. 2.

From Fig. 2, it is seen that the texture of an image gets enhanced by changing the fractional differential order. For G-L FD mask, the texture of image first increases with increase in fractional differential order but exceeding the fractional differential order beyond some value results in distortion of image. With R-L FD mask, there is slight enhancement in texture of image with an increase in fractional differential order, but the degree of enhancement decreases after some point with the further increase in fractional differential order. Processing of image with Improved G-L FD mask results in enhancement of texture of image with an increase in fractional order but as compared to G-L FD mask the distortion is less with the further increase in fractional differential order.

For quantity analysis, the FD masks are implemented on different images and its effect on information entropy and average gradient of image are shown in Table I. The average gradient reflects the clarity of the image. It can be used to measure the spatial resolution of the image, i.e., a larger average gradient means a higher spatial resolution. The information entropy shows the average information included in the image and reflects the detail information of the image.

Carefully observing Table $\mathrm{I}$ it is seen that the information entropy and average gradient of the image first increase with the fractional differential order thus enhancing the textural information of the image. However, after attaining a certain maximum value the information entropy starts decreasing results in loss of textural information and hence distortion of image. The R-L FD Mask provides slight improvement of approximately 0.2 in information entropy with an increase in fractional differential order but if the fractional order is exceeded beyond 0.4 , the information entropy starts decreasing and at $\mathrm{v}=1$ the entropy reaches its lowest value. Image processing through G-L FD Mask increases the information entropy of image by 0.5 and attains a maximum value at $\mathrm{v}=$ 0.4 thus enhancing texture, however, increasing the fractional order beyond 0.4 results in decrease in information entropy and hence distortion of image.

However, with the improved G-L FD Mask the maximum information entropy achieved at fractional differential order $\mathrm{v}=$ 0.4 is more than both G-L, and R-L FD Masks thus providing more textural information. Also the decrease in information entropy through an improved G-L FD Mask with the further increase in fractional order beyond 0.4 is less than other FD Masks resulting in less distortion of image.

\section{B. The Intensity Factor}

From (13) the value of fractional differential order is kept constant at $\mathrm{v}=0.2$ and intensity factor $\gamma$ is varied for $1<\gamma<2$. The intensity factor $\gamma$ is also the scale for controlling the degree of enhancement. The simulated results are presented in Fig. 3.

Observing the Fig. 3 it is seen that texture channel becomes deeper and texture details are clearer [16] with an increase in intensity factor of Improved G-L Fractional Differential mask. Improved G-L Fractional Differential mask can not only maintain the most energy of image on the low frequency, but also nonlinearly enhance its energy over intermediate and high frequency, which leads to richer texture details. For quantity analysis, information entropy and average gradient are taken as parameters, which are shown in Table II.

From Table II it is observed that with an increase in intensity factor of Fractional Differential mask, the information entropy and average gradient of the image start increasing. The information entropy reaches its maximum value at intensity factor $\gamma=1.8$, thus nonlinearly preserve the low-frequency contour feature in the smooth area to the high degree. But as the intensity factor is increased beyond 1.8, the information entropy starts decreasing resulting in loss of textural information.

\begin{tabular}{|c|c|c|c|c|c|}
\hline $\begin{array}{c}\text { Intensity } \\
\text { Factor }\end{array}$ & $\begin{array}{c}\text { Information } \\
\text { Entropy }\end{array}$ & $\begin{array}{c}\text { Average } \\
\text { Gradient }\end{array}$ & $\begin{array}{c}\text { Intensity } \\
\text { Factor }\end{array}$ & $\begin{array}{c}\text { Information } \\
\text { Entropy }\end{array}$ & $\begin{array}{c}\text { Average } \\
\text { Gradient }\end{array}$ \\
\hline 0 & 7.1677 & 9.0446 & 1.5 & 7.6823 & 27.6426 \\
\hline 1.0 & 7.5716 & 21.2197 & 1.6 & 7.6923 & 28.9346 \\
\hline 1.1 & 7.6035 & 22.4979 & 1.7 & 7.6975 & 30.2284 \\
\hline 1.2 & 7.6288 & 23.7798 & 1.8 & 7.6991 & 31.5237 \\
\hline 1.3 & 7.6518 & 25.0648 & 1.9 & 7.6963 & 32.8204 \\
\hline 1.4 & 7.6695 & 26.3525 & 2.0 & 7.6885 & 34.1183 \\
\hline
\end{tabular}

\section{CONCLUSION}

In this paper, an improved G-L Fractional Differential mask is presented, which can enhance both texture and lightness of image. The Fractional Differential mask presented can control the degree of texture enhancement with Fractional Differential order $\mathrm{v}$ and intensity factor $\gamma$. And from quantitative analysis, it is observed that improvement of information entropy of image through improved G-L FD mask is more than both G-L and RL FD Masks, thus enhancing more textural information. However, through all the FD Masks the image gets distorted if the value of intensity factor and fractional differential order is exceeded above certain value. The FD mask discussed, can be implemented further on real time images like remote sensed images, fingerprint images collected from the crime scene, etc., to enhance texture of these images, which is the subject of future work. 


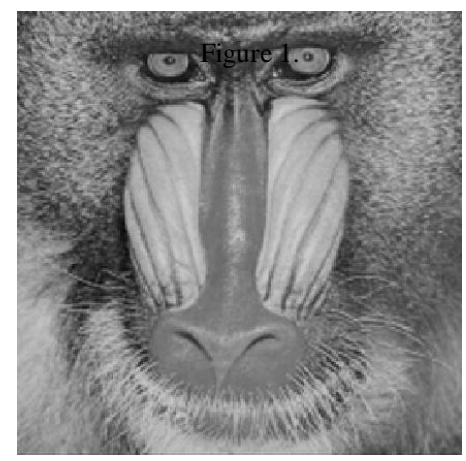

(a) $\mathrm{v}=0$

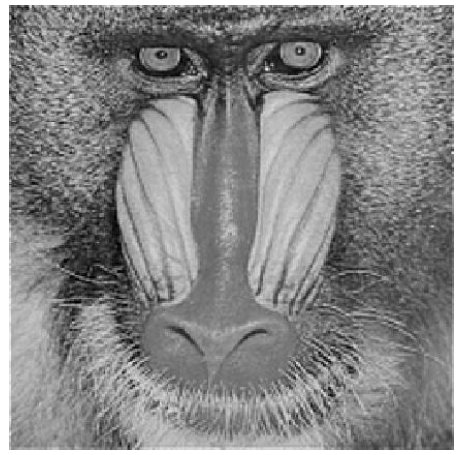

(b) $v=0.1$ G-L FD

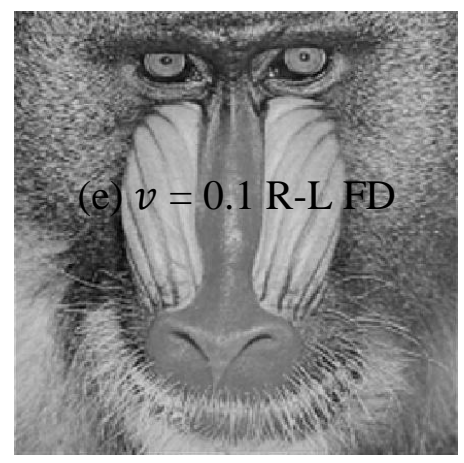

(f) $v=0.1$ G-L FD

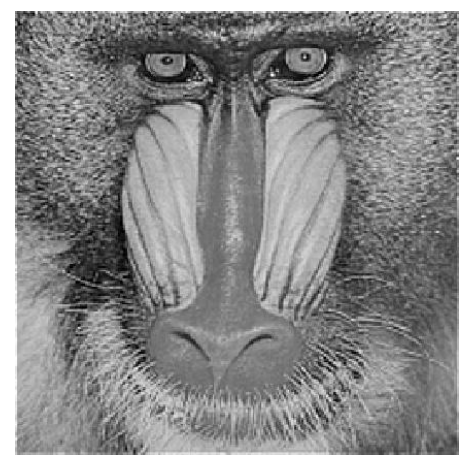

(i) $\mathrm{v}=0.1$ Improved G-L FD

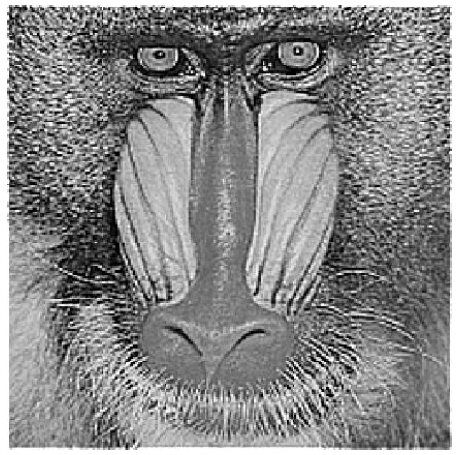

(c) $v=0.4$ G-L FD

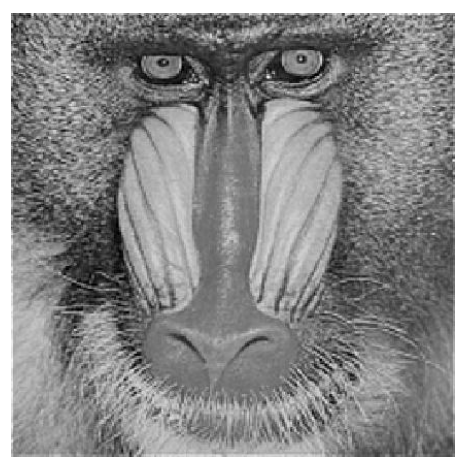

(g) $\mathrm{v}=0.4$ R-L FD

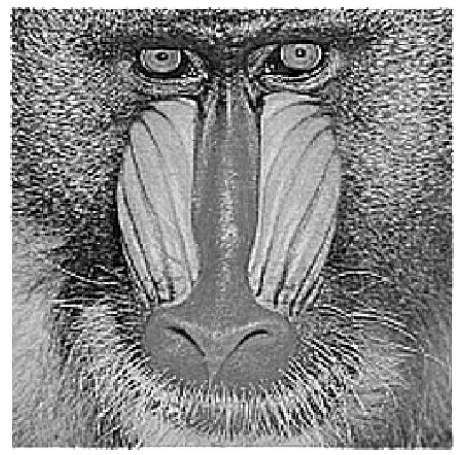

(j) $\mathrm{v}=0.4$ Improved G-L FD

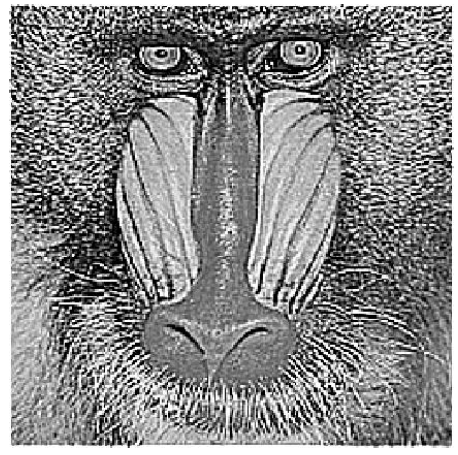

(d) $v=1$ G-L FD

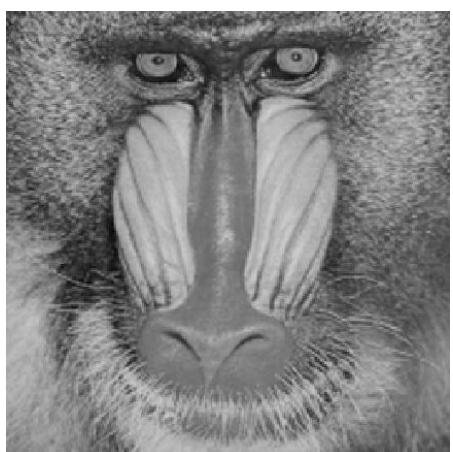

(h) $v=1$ R-L FD

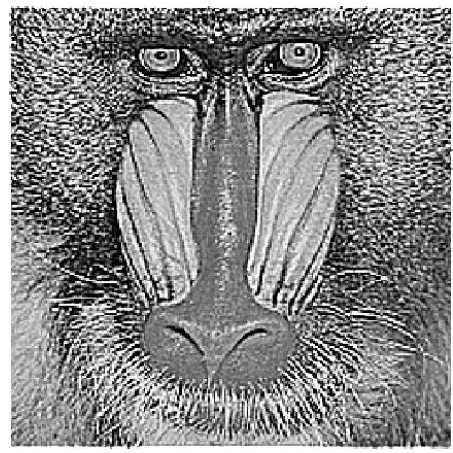

(k) v = 1 Improved G-L FD

Figure 2: Texture enhancement of Baboon Image with intensity factor $\gamma=1$ for different values of fractional order (v) through different types of FD masks. 
TABLE I. INFORMATION ENTROPY AND AVERAGE GRADIENT For VARIOUS IMAGES PROCESSED THROUGH DIFFERENT FD MASKS

\begin{tabular}{|c|c|c|c|c|c|c|c|c|c|c|c|c|c|c|c|c|c|c|}
\hline \multirow[b]{3}{*}{$\begin{array}{l}\text { FD } \\
\text { Orde } \\
\text { r }\end{array}$} & \multicolumn{9}{|c|}{ Information Entropy } & \multicolumn{9}{|c|}{ Average Gradient } \\
\hline & \multicolumn{3}{|c|}{ G-L FD Mask } & \multicolumn{3}{|c|}{ R-L FD Mask } & \multicolumn{3}{|c|}{$\begin{array}{c}\text { Improved G-L FD } \\
\text { Mask }\end{array}$} & \multicolumn{3}{|c|}{ G-L FD Mask } & \multicolumn{3}{|c|}{ R-L FD Mask } & \multicolumn{3}{|c|}{$\begin{array}{c}\text { Improved G-L FD } \\
\text { Mask }\end{array}$} \\
\hline & Babo & $\begin{array}{c}\text { Brid } \\
\text { ge }\end{array}$ & $\begin{array}{c}\text { Moo } \\
\text { n } \\
\text { Surf } \\
\text { ace }\end{array}$ & $\begin{array}{c}\text { Babo } \\
\text { on }\end{array}$ & $\begin{array}{l}\text { Brid } \\
\text { ge }\end{array}$ & $\begin{array}{c}\text { Moo } \\
\text { n } \\
\text { Surf } \\
\text { ace }\end{array}$ & $\begin{array}{c}\text { Babo } \\
\text { on }\end{array}$ & $\begin{array}{l}\text { Brid } \\
\text { ge }\end{array}$ & $\begin{array}{c}\text { Moo } \\
\mathrm{n} \\
\text { Surf } \\
\text { ace }\end{array}$ & $\begin{array}{c}\text { Babo } \\
\text { on }\end{array}$ & $\begin{array}{l}\text { Brid } \\
\text { ge }\end{array}$ & $\begin{array}{c}\text { Moo } \\
\mathrm{n} \\
\text { Surfa } \\
\text { ce }\end{array}$ & $\begin{array}{c}\text { Babo } \\
\text { on }\end{array}$ & $\begin{array}{l}\text { Brid } \\
\text { ge }\end{array}$ & $\begin{array}{c}\text { Moo } \\
\mathrm{n} \\
\text { Surfa } \\
\text { ce }\end{array}$ & $\begin{array}{c}\text { Babo } \\
\text { on }\end{array}$ & $\begin{array}{l}\text { Brid } \\
\text { ge }\end{array}$ & $\begin{array}{c}\text { Moo } \\
\text { n } \\
\text { Surfa } \\
\text { ce }\end{array}$ \\
\hline 0 & $\begin{array}{l}7.16 \\
86\end{array}$ & $\begin{array}{l}7.72 \\
85\end{array}$ & $\begin{array}{l}7.03 \\
31\end{array}$ & $\begin{array}{l}7.16 \\
86\end{array}$ & $\begin{array}{l}7.72 \\
85\end{array}$ & $\begin{array}{l}7.03 \\
31\end{array}$ & $\begin{array}{l}7.16 \\
86\end{array}$ & $\begin{array}{l}7.72 \\
84\end{array}$ & $\begin{array}{l}7.03 \\
31\end{array}$ & $\begin{array}{l}9.15 \\
36\end{array}$ & $\begin{array}{l}8.39 \\
62\end{array}$ & $\begin{array}{l}10.3 \\
749\end{array}$ & $\begin{array}{l}9.15 \\
36\end{array}$ & $\begin{array}{l}8.39 \\
62\end{array}$ & $\begin{array}{l}10.3 \\
749\end{array}$ & $\begin{array}{l}9.15 \\
36\end{array}$ & $\begin{array}{l}8.39 \\
62\end{array}$ & $\begin{array}{l}10.3 \\
749\end{array}$ \\
\hline 0.1 & $\begin{array}{l}7.33 \\
20 \\
\end{array}$ & $\begin{array}{l}7.76 \\
57\end{array}$ & $\begin{array}{l}7.13 \\
49 \\
\end{array}$ & $\begin{array}{l}7.22 \\
85\end{array}$ & $\begin{array}{l}7.74 \\
43\end{array}$ & $\begin{array}{l}7.05 \\
62\end{array}$ & $\begin{array}{l}7.37 \\
88 \\
\end{array}$ & $\begin{array}{l}7.77 \\
44\end{array}$ & $\begin{array}{l}7.16 \\
98\end{array}$ & $\begin{array}{l}13.8 \\
149\end{array}$ & $\begin{array}{l}10.3 \\
266\end{array}$ & $\begin{array}{l}14.9 \\
990\end{array}$ & $\begin{array}{l}11.1 \\
102\end{array}$ & $\begin{array}{l}9.20 \\
84\end{array}$ & $\begin{array}{l}12.3 \\
481\end{array}$ & $\begin{array}{l}15.0 \\
309\end{array}$ & $\begin{array}{l}10.8 \\
352\end{array}$ & $\begin{array}{l}16.1 \\
845\end{array}$ \\
\hline 0.2 & $\begin{array}{l}7.50 \\
74\end{array}$ & $\begin{array}{l}7.80 \\
07\end{array}$ & $\begin{array}{l}7.26 \\
87\end{array}$ & $\begin{array}{l}7.28 \\
37\end{array}$ & $\begin{array}{l}7.75 \\
60\end{array}$ & $\begin{array}{l}7.09 \\
65\end{array}$ & $\begin{array}{l}7.57 \\
15\end{array}$ & $\begin{array}{l}7.81 \\
36\end{array}$ & $\begin{array}{l}7.31 \\
97\end{array}$ & $\begin{array}{l}18.8 \\
088\end{array}$ & $\begin{array}{l}12.4 \\
448\end{array}$ & $\begin{array}{l}19.8 \\
604\end{array}$ & $\begin{array}{l}12.5 \\
891\end{array}$ & $\begin{array}{l}9.81 \\
76\end{array}$ & $\begin{array}{l}13.8 \\
012\end{array}$ & $\begin{array}{l}21.2 \\
196\end{array}$ & $\begin{array}{l}13.4 \\
902\end{array}$ & $\begin{array}{l}22.2 \\
057\end{array}$ \\
\hline 0.3 & $\begin{array}{l}7.63 \\
10 \\
\end{array}$ & $\begin{array}{l}7.82 \\
48\end{array}$ & $\begin{array}{l}7.36 \\
60 \\
\end{array}$ & $\begin{array}{l}7.32 \\
00\end{array}$ & $\begin{array}{l}7.76 \\
34\end{array}$ & $\begin{array}{l}7.12 \\
58\end{array}$ & $\begin{array}{l}7.67 \\
89\end{array}$ & $\begin{array}{l}7.83 \\
35\end{array}$ & $\begin{array}{l}7.40 \\
85\end{array}$ & $\begin{array}{l}23.9 \\
133\end{array}$ & $\begin{array}{l}14.6 \\
722\end{array}$ & $\begin{array}{l}24.8 \\
279\end{array}$ & $\begin{array}{l}13.5 \\
149\end{array}$ & $\begin{array}{l}10.2 \\
014\end{array}$ & $\begin{array}{l}14.7 \\
061\end{array}$ & $\begin{array}{l}27.3 \\
150 \\
\end{array}$ & $\begin{array}{l}16.1 \\
821\end{array}$ & $\begin{array}{l}28.1 \\
421 \\
\end{array}$ \\
\hline 0.4 & $\begin{array}{l}7.69 \\
32 \\
\end{array}$ & $\begin{array}{l}7.83 \\
51 \\
\end{array}$ & $\begin{array}{l}7.42 \\
40 \\
\end{array}$ & $\begin{array}{l}7.33 \\
50 \\
\end{array}$ & $\begin{array}{l}7.76 \\
63 \\
\end{array}$ & $\begin{array}{l}7.13 \\
78 \\
\end{array}$ & $\begin{array}{l}7.69 \\
47 \\
\end{array}$ & $\begin{array}{l}7.83 \\
24 \\
\end{array}$ & $\begin{array}{l}7.44 \\
56 \\
\end{array}$ & $\begin{array}{l}29.0 \\
690 \\
\end{array}$ & $\begin{array}{l}16.9 \\
668 \\
\end{array}$ & $\begin{array}{l}29.8 \\
521 \\
\end{array}$ & $\begin{array}{l}13.9 \\
022 \\
\end{array}$ & $\begin{array}{l}10.3 \\
630 \\
\end{array}$ & $\begin{array}{l}15.0 \\
842 \\
\end{array}$ & $\begin{array}{l}33.1 \\
318 \\
\end{array}$ & $\begin{array}{l}18.7 \\
966 \\
\end{array}$ & $\begin{array}{l}33.8 \\
149 \\
\end{array}$ \\
\hline 0.5 & $\begin{array}{l}7.68 \\
99\end{array}$ & $\begin{array}{l}7.82 \\
97\end{array}$ & $\begin{array}{l}7.45 \\
05\end{array}$ & $\begin{array}{l}7.33 \\
09\end{array}$ & $\begin{array}{l}7.76 \\
52\end{array}$ & $\begin{array}{l}7.13 \\
41\end{array}$ & $\begin{array}{l}7.65 \\
59\end{array}$ & $\begin{array}{l}7.81 \\
46\end{array}$ & $\begin{array}{l}7.44 \\
95\end{array}$ & $\begin{array}{l}34.2 \\
533\end{array}$ & $\begin{array}{l}19.3 \\
043\end{array}$ & $\begin{array}{l}34.9 \\
093\end{array}$ & $\begin{array}{l}13.8 \\
020\end{array}$ & $\begin{array}{l}10.3 \\
212\end{array}$ & $\begin{array}{l}14.9 \\
864\end{array}$ & $\begin{array}{l}38.5 \\
195\end{array}$ & $\begin{array}{l}21.2 \\
432\end{array}$ & $\begin{array}{l}39.0 \\
734\end{array}$ \\
\hline 0.6 & $\begin{array}{l}7.64 \\
55 \\
\end{array}$ & $\begin{array}{l}7.81 \\
04 \\
\end{array}$ & $\begin{array}{l}7.44 \\
83 \\
\end{array}$ & $\begin{array}{l}7.31 \\
10 \\
\end{array}$ & $\begin{array}{l}7.76 \\
15 \\
\end{array}$ & $\begin{array}{l}7.11 \\
82 \\
\end{array}$ & $\begin{array}{l}7.58 \\
82 \\
\end{array}$ & $\begin{array}{l}7.78 \\
77 \\
\end{array}$ & $\begin{array}{l}7.43 \\
25 \\
\end{array}$ & $\begin{array}{l}39.4 \\
552 \\
\end{array}$ & $\begin{array}{l}21.6 \\
699 \\
\end{array}$ & $\begin{array}{l}39.9 \\
870 \\
\end{array}$ & $\begin{array}{l}13.2 \\
892 \\
\end{array}$ & $\begin{array}{l}10.1 \\
077 \\
\end{array}$ & $\begin{array}{l}14.4 \\
857 \\
\end{array}$ & $\begin{array}{l}43.3 \\
330 \\
\end{array}$ & $\begin{array}{l}23.4 \\
429 \\
\end{array}$ & $\begin{array}{l}43.7 \\
740 \\
\end{array}$ \\
\hline 0.7 & $\begin{array}{l}7.56 \\
12\end{array}$ & $\begin{array}{l}7.77 \\
83\end{array}$ & $\begin{array}{l}7.42 \\
47\end{array}$ & $\begin{array}{l}7.27 \\
85\end{array}$ & $\begin{array}{l}7.75 \\
52\end{array}$ & $\begin{array}{l}7.09 \\
18\end{array}$ & $\begin{array}{l}7.50 \\
64\end{array}$ & $\begin{array}{l}7.75 \\
58\end{array}$ & $\begin{array}{l}7.40 \\
58\end{array}$ & $\begin{array}{l}44.6 \\
685\end{array}$ & $\begin{array}{l}24.0 \\
549\end{array}$ & $\begin{array}{l}45.0 \\
785\end{array}$ & $\begin{array}{l}12.4 \\
565\end{array}$ & $\begin{array}{l}9.76 \\
27\end{array}$ & $\begin{array}{l}13.6 \\
713\end{array}$ & $\begin{array}{l}47.4 \\
248\end{array}$ & $\begin{array}{l}25.3 \\
203\end{array}$ & $\begin{array}{l}47.7 \\
712\end{array}$ \\
\hline 0.8 & $\begin{array}{l}7.45 \\
73 \\
\end{array}$ & $\begin{array}{l}7.73 \\
35\end{array}$ & $\begin{array}{l}7.38 \\
45 \\
\end{array}$ & $\begin{array}{l}7.23 \\
99\end{array}$ & $\begin{array}{l}7.74 \\
69 \\
\end{array}$ & $\begin{array}{l}7.06 \\
18 \\
\end{array}$ & $\begin{array}{l}7.44 \\
38 \\
\end{array}$ & $\begin{array}{l}7.72 \\
60\end{array}$ & $\begin{array}{l}7.37 \\
73\end{array}$ & $\begin{array}{l}49.8 \\
898 \\
\end{array}$ & $\begin{array}{l}26.4 \\
539\end{array}$ & $\begin{array}{l}50.1 \\
797 \\
\end{array}$ & $\begin{array}{l}11.4 \\
099\end{array}$ & $\begin{array}{l}9.33 \\
16 \\
\end{array}$ & $\begin{array}{l}12.6 \\
437\end{array}$ & $\begin{array}{l}50.6 \\
421 \\
\end{array}$ & $\begin{array}{l}26.8 \\
003 \\
\end{array}$ & $\begin{array}{l}50.9 \\
149 \\
\end{array}$ \\
\hline 0.9 & $\begin{array}{l}7.34 \\
82\end{array}$ & $\begin{array}{l}7.68 \\
07\end{array}$ & $\begin{array}{l}7.32 \\
48 \\
\end{array}$ & $\begin{array}{l}7.20 \\
08\end{array}$ & $\begin{array}{l}7.73 \\
74\end{array}$ & $\begin{array}{l}7.04 \\
11\end{array}$ & $\begin{array}{l}7.39 \\
65\end{array}$ & $\begin{array}{l}7.70 \\
35\end{array}$ & $\begin{array}{l}7.35 \\
40\end{array}$ & $\begin{array}{l}55.1 \\
167\end{array}$ & $\begin{array}{l}28.8 \\
634\end{array}$ & $\begin{array}{l}55.2 \\
880\end{array}$ & $\begin{array}{l}10.2 \\
666\end{array}$ & $\begin{array}{l}8.86 \\
12\end{array}$ & $\begin{array}{l}11.5 \\
095\end{array}$ & $\begin{array}{l}52.8 \\
257\end{array}$ & $\begin{array}{l}27.8 \\
065\end{array}$ & $\begin{array}{l}53.0 \\
489\end{array}$ \\
\hline 1.0 & $\begin{array}{l}7.23 \\
79\end{array}$ & $\begin{array}{l}7.62 \\
06\end{array}$ & $\begin{array}{l}7.25 \\
36\end{array}$ & $\begin{array}{l}7.16 \\
86\end{array}$ & $\begin{array}{l}7.72 \\
84\end{array}$ & $\begin{array}{l}7.03 \\
31\end{array}$ & $\begin{array}{l}7.37 \\
54\end{array}$ & $\begin{array}{l}7.69 \\
40\end{array}$ & $\begin{array}{l}7.34 \\
30\end{array}$ & $\begin{array}{l}60.3 \\
477\end{array}$ & $\begin{array}{l}31.2 \\
808\end{array}$ & $\begin{array}{l}60.4 \\
017\end{array}$ & $\begin{array}{l}9.15 \\
37\end{array}$ & $\begin{array}{l}8.39 \\
62\end{array}$ & $\begin{array}{l}10.3 \\
749\end{array}$ & $\begin{array}{l}53.8 \\
095\end{array}$ & $\begin{array}{l}28.2 \\
602\end{array}$ & $\begin{array}{l}54.0 \\
104\end{array}$ \\
\hline
\end{tabular}

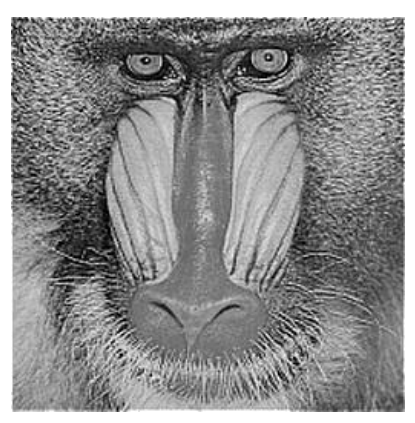

(a) $\gamma=1$

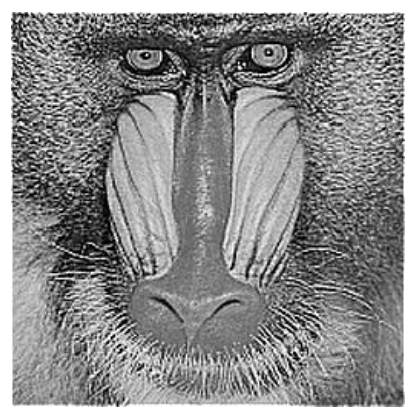

(c) $\gamma=1.9$

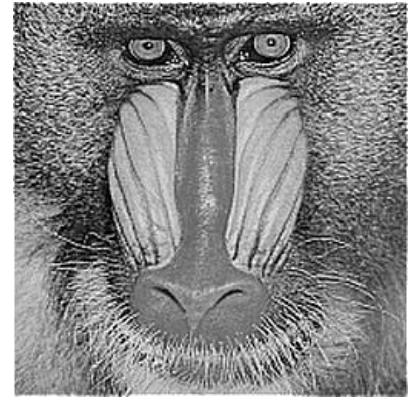

(b) $\gamma=1.5$

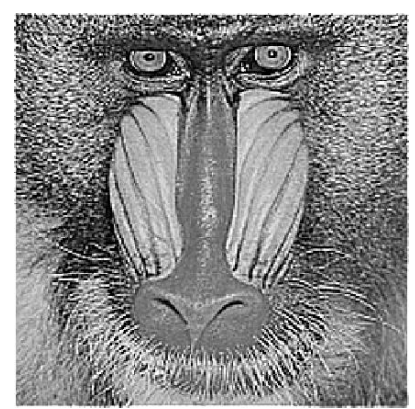

(d) $\gamma=2.0$
Figure 3. Texture enhancement of Image with fractional order $v=0.2$ for different values of intensity factor $\gamma$

\section{ACKNOWLEDGMENT}

The authors are thankful to unanimous reviewers for their valuable suggestions.

\section{REFERENCES}

[1] R. M. Haralick, K. Shanmugam and Its'Hak Dinstein, "Textural Features for Image Classification", IEEE Transaction on Systems, Man and Cybernetics, vol. 3, issue 6, pp. 610-621, 1973.

[2] Salem Saleh Al-amri, Dr. N. V. Kalyankar and Dr. S. D. Khamitkar, "Linear and Non-linear Contrast Enhancement Image", International Journal of Computer Science and Network Security, vol. 10, issue 2, pp. 139-143, 2010.

[3] P. J. Burt and E. H. Adelson, "The Laplacian pyramid as a compact image code", IEEE Transaction on Communication, vol. COM-31, issue 4, pp. 532-540, 1983.

[4] S. Dippel, M. Stahl, R. Wiemker, and T. Blaffert, "Multiscale contrast enhancement for radiographies: Laplacian pyramid versus fast wavelet transform", IEEE Transaction on Medical Imaging, vol. 21, issue 4, pp. 343-353, 2002.

[5] J. L. Starck, F. Murtagh, E. Candes, and D. Donoho, "Gray and color image contrast enhancement by the curvelet transform", IEEE Transaction on Image Processing, vol. 12, issue 6, pp. 706-717, 2003.

[6] M. N. Do and M. Vetterli, "The Contourlet transform: An efficient directional multiresolution image representation", IEEE Transaction on Image Processing, vol. 14, issue 12, pp. 2091-2106, 2005.

[7] E. R. Love, "Fractional derivatives of imaginary order", Journal of London Mathematical Society, vol. 3, pp. 241-259, 1971.

[8] K. B. Oldham and Spanier, The Fractional Calculus: Integrations and Differentiations of Arbitrary Order. New York: Academic, 1974. 
[9] K. Nishimoto, Fractional Calculus. New Haven, CT: Univ. New Haven Press, 1989.

[10] Yi-Fei Pu, "Fractional Calculus Approach to Texture of Digital Image", 8th International Conference on Signal Processing, 2007.

[11] Zhuzhong Yang, Fangnian Lang, Xiaohong Yu and Yu Zhang, "The Construction of Fractional Differential Gradient Operator", Journal of Computational Information Systems, vol. 7, issue 12, pp. 4328-4342, 2011.

[12] Yawei Liu, "Remote Sensing Image Enhancement Based on Fractional Differential", International Conference on Computational and Information Science, pp. 881-884, 2010.

[13] Yi Zhang, Yi-Fei Pu and Jiliu Zhou, "Construction of Fractional differential Masks Based on Riemann-Liouville Definition", Journal of Computational Information Systems, vol. 6, issue 10, pp. 3191-3199, 2010.

[14] Zhifeng Gan and Hongyu Yang, "Texture Enhancement though Multiscale Mask based on RL Fractional Differential", International Conference on Information Networking and Automation, vol. 1, pp. 333337, 2010.

[15] Yi-Fei Pu, Zhou Ji-Liu, and Yuan Xiao, "Fractional Differential Mask: A Fractional Differential-Based Approach for Multiscale Texture Enhancement", IEEE Transactions on Image Processing, vol. 19, issue 2, pp. 491-511, 2010.
[16] Gao Chaobang, Zhou Ji-Liu, Zheng Xiuqing and Lang Fangnian, "Image Enhancement Based on Improved Fractional Differentiation", Journal of Computational Information System, vol. 7, issue 1, pp. 257-264, 2011.

\section{AUTHORS PROFILE}

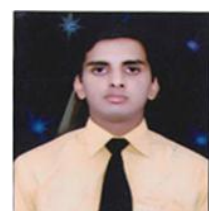

Vishwadeep Garg was born in Bathinda (Punjab). He received his B.Tech in Electronics and Communication Engineering from PTU, Jalandhar. He has completed his M.E in Electronics and Communication Engineering from Thapar University, Patiala. His research interest includes Digital Image Processing, and Digital Signal Processing.

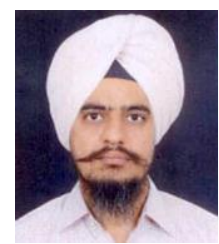

Dr. Kulbir Singh was born in Batala $(\mathrm{Pb}) \quad$ India. He received his BTech degree in 1997 from PTU, Jalandhar. He obtained his ME and Ph.D. degree from Thapar Institute of Engineering and Technology, Patiala in 2000 and 2006 respectively. He worked as lecturer from 2000 to 2007, Assistant Professor from 2007 to 2010 in Electronics and Communication Engineering Department, Thapar University, Patiala. Presently he is working as Associate Professor at Thapar University, Patiala since June 2010. He has published about 65 research articles in refereed international and national journals, international conference and national conference. He is life time member of IETE and ISTE. His research interests include Digital Signal Processing, Image Processing, Fractional Fourier Transform and Communication systems. 